\title{
Die STAND VAN PSALMSANG IN DIE NG KERK
}

Authors:

Hendrika J. Jankowitz ${ }^{1}$

Daleen Kruger ${ }^{2}$

\section{Affiliations:}

${ }^{1}$ Skool vir Musiek,

Noordwes-Universiteit,

Potchefstroomkampus,

Suid-Afrika

\section{Correspondence to:}

Hendrika Jankowitz

email:

3kie@iway.na

Postal address:

Posbus 30247, Windhoek 9000, Namibië

Keywords:

Psalmsang; NG Kerk;

Afrikaanse psalmtekste;

Afrikaanse psalmmelodieë;

liturgiese psalmsang;

Liedboek (2001)

Dates:

Received: 26 May 2010

Accepted: 17 Sept. 2010

Published: 18 Nov. 2010

How to cite this article: Jankowitz, H.J. \& Kruger, D., 2010, 'Die stand van psalmsang in die NG Kerk', Verbum et Ecclesia 31(1),

Art. \#400, 10 pages. DOI:

10.4102/ve.v31i1.400

This article is available at:

http://www.ve.org.za

Note:

Hierdie studie is onder leiding van prof. Daleen Kruger gedoen, in samewerking met die Statistiese Konsultasiediens van Noordwes-Universiteit.

(C) 2010. The Authors.

Licensee: OpenJournals

Publishing. This work

is licensed under the

Creative Commons

Attribution License.

\section{ABSTRACT}

The status of psalm singing in the Dutch Reformed Church

Over the past three decades, there have been consistent and increasing signs that psalms are disappearing from the repertoire of hymns that are sung in the Dutch Reformed (DR) Church. In an attempt to turn this tendency around, research was undertaken to determine the seriousness and the cause of the current situation. An empirical study was done to determine the frequency of use and the functionality of psalms, and to identify the practical factors that influence these.

Results confirmed the low application frequency, dysfunctionality, unpopularity and sparse liturgical employment of psalms, and showed that most psalms that appear in the hymn book of the Church, Liedboek (2001), have not become part of the repertoire of hymns of the DR Church. Respondents also provided valuable information in their explanations of why psalms are out of touch with the needs of congregations in contemporary Afrikaans culture.

The research concluded that psalm singing is falling into disuse in the DR Church in South Africa. Only a small number of psalms stand a chance to survive, and then only in congregations where the singing of psalms is propagated, where well-known psalms are sung regularly and where new psalms are being learned.

\section{INLEIDING}

\section{Agtergrond}

Die sing van psalms behoort ' $n$ allesinsluitende, vreugdevolle geloofsbelewenis van die Kerk te wees. In die NG Kerk in Suid-Afrika het daar sedert die laaste dekades van die 20ste eeu egter al hoe meer tekens na vore gekom dat hierdie hoofliedbundel van die Bybel, soos in die formaat van die 1978-bundel, nie aan hierdie doel beantwoord nie, en dat psalmsang gevolglik traag en stemloos geword het. Daarom is met groot afwagting na die Liedboek (2001) uitgesien.

In die Liedboek (2001) is die psalms in meer byderwetse Afrikaans omgedig en is ongeveer 60 Geneefse melodieë met makliker singbare melodieë vervang (Barnard 2001:15). Vos (2005:355) wys daarop dat die 2001-omdigtings die liturgiese bruikbaarheid van die psalms grootliks versterk het, maar volgens Strauss (2005:14) is dit nog nie liturgies verpak om met die tydsgewrig waarin ons leef, tred te hou nie. Die vermoede het gegroei dat psalmgebruik aan die afneem is. Blykbaar kon die stigma wat voorheen aan die psalms gekleef het (Viljoen 1997:59,62,117,122,124,129; Fourie 2000:268-269), nie uitgewis word nie, en is die dalende tendens van psalmgebruik nie deur die 2001-hervormings gestuit nie.

As ' $n$ eerste stap in ' $n$ moontlike oplossing van die probleem was dit nodig om die toedrag van sake noukeurig te bepaal. Gevolglik is daar op ' $n$ empiriese navorsingstudie besluit om die gebruiksfrekwensie en funksionaliteit van die bestaande psalmbundel te bepaal. Respondente se menings sou ook kon aandui watter benadering, psalmformate en psalmstyle wél in die eietydse, plaaslike behoeftes van die NG Kerk kan voorsien.

In hierdie artikel word die resultate van die navorsing bespreek na aanleiding van die belangrikste data wat deur die vraelys ingesamel is. Bevindings word, waar toepaslik, grafies weergegee en bespreek. Ten slotte word afleidings gemaak oor die stand van psalmsang, en die faktore wat daartoe aanleiding gegee het.

\section{Oorsig van literatuur}

Daar bestaan tot dusver geen grondige empiriese navorsing oor die gebruiksfrekwensie van psalms in die NG Kerk nie. Een empiriese studie waarin die funksionaliteit van psalms onder meer bespreek word, is deur Viljoen (1997) onderneem. Sy het lesers se menings oor liturgiese sang in die tydperk 1959-1994, soos dit in Die Kerkbode gelug is, getoets en beskryf. Roux (1985) het weer ' $n$ kwalitatiewe studie, 'Grondbeginsels van die Gereformeerde Kerklied met verwysing na die 1978-Psalm en Gesangboek', onderneem waarin die psalms onder meer bespreek is. As deel van dié DPhil-proefskrif word insiggewende redes aangevoer waarom Suid-Afrikaanse gemeentes dit moeilik vind om psalms met oorgawe te sing.

Agtergrondkennis oor psalms en psalmsang kon versamel word deur onder meer die literatuur van die gerekende himnoloë en teoloë Brueggemann (1984), Fourie (2000), Vos (2005) en Strauss (2005) te bestudeer. Hierdie kennis kon as riglyne aangewend word om te bepaal watter fasette of tendense in hierdie studie getoets behoort te word. Die artikel is egter hoofsaaklik op 'n empiriese studie gegrond wat die outeur in 2008 onderneem het (Jankowitz 2009).

\section{METODE VAN ONDERSOEK}

Deur middel van ' $n$ kwantitatiewe navorsingsmetode is ' $n$ empiriese studie met vraelyste onderneem. Vraelyste is elektronies aan gemeentes uitgestuur, en 150 daarvan is verwerk. Die demografiese besonderhede van die gemeentes is soos volg: 
- $\quad$ makrogemeentes $=11$

- $\quad$ mikrogemeentes sonder orrelis $=4$

- $\quad$ stedelike gemeentes $=62$

- $\quad$ plattelandse gemeentes $=74$

- $\quad$ gemeentes met ' $n$ jeugfokus = 10

- $\quad$ hipermoderne gemeentes wat slegs kontemporêre begeleiding gebruik $=11$

- gemeentes wat grootliks uit bejaardes bestaan $=16$.

In die bespreking wat volg, verwys die term 'gemeentes' na hierdie respondentgemeentes wat deel was van hierdie steekproef, tensy die teendeel uit die konteks blyk.

Die data word vervolgens getoon en bespreek ooreenkomstig die vrae wat gestel is. Bevindings en afleidings na aanleiding van die data word telkens gegee, en grafieke word, waar toepaslik, ter illustrasie gebruik.

\section{RESULTATE VAN DIE STATISTIESE ONDERSOEK}

\section{Die gebruiksfrekwensie van psalms}

Verskillende vrae is gebruik om die gebruiksfrekwensie van psalms uit 'n verskeidenheid perspektiewe te bepaal. Die hoeveelheid gemeentes wat psalms sing, die hoeveelheid geleenthede vir psalmsang per erediens, en die gemiddelde hoeveelheid kere per Sondag wat psalms gesing word, is onder meer deur die vrae gedek. Hierdie data sou ook kon aandui by hoeveel geleenthede nuwe psalms aangeleer kan word. Die vrae, tersaaklike grafieke, data uitgedruk as persentasies, 'n analise van die data, en die gevolgtrekkings daaruit word vervolgens uiteengesit.

\section{Word psalms voor die erediens en/of tydens die erediens gesing?}

Uit hierdie vraag is vasgestel dat $62 \%$ van die gemeentes voor die erediens, en $84 \%$ gemeentes tydens die erediens psalms sing. Wanneer die data ontleed word, lyk dié persentasies hoog. Daar moet egter in gedagte gehou word dat dié resultate 'n weerspieëling is dat psalmsang wél plaasvind, en nie van die hoeveelheid psalms wat gesing word of die aantal eredienste waartydens psalms gesing word nie.

Aangesien $62 \%$ van die gemeentes (by geleentheid) voor, en $84 \%$ tydens die erediens psalms sing, blyk dit dat daar ' $n$ gewilligheid vir die sing van psalms bestaan, en dat sommige gemeenteleiers doelbewus psalms by die beplanning van 'n erediens insluit.

\section{Hoeveel keer per Sondag word psalms gesing?}

Hierdie vraag kon die gemiddelde aantal psalms wat per Sondag gesing word, bepaal. Die resultate word deur middel van die sektordiagram in grafiek 1 aangedui, waarin gemeentes volgens die aantal psalms wat per Sondag gesing word ingedeel is.

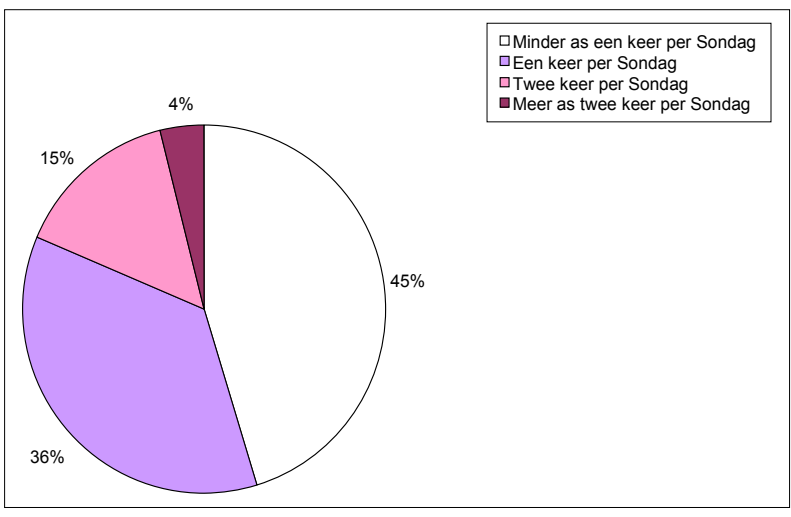

GRAFIEK 1

Hoeveek keer per Sondag word psamls gesing?
Die data in grafiek 1 toon dat 45.3\% van die gemeentes minder as een keer per Sondag, $36 \%$ van die gemeentes een keer per Sondag, $14.6 \%$ van die gemeentes twee keer per Sondag, en $4 \%$ meer as twee keer per Sondag psalms sing. Dit is opvallend dat naastenby die helfte van gemeentes minder as een psalm per Sondag sing. Wanneer die persentasie gemeentes wat een maal per Sondag ' $n$ psalm sing hierby gereken word $(45.3 \%+36.0 \%)$, beteken dit dat $81.3 \%$ van gemeentes geen of hoogstens een psalm per Sondag sing. Die totale persentasie gemeentes waar psalms twee of meer keer per Sondag gesing word, is $18.6 \%$ $(14.6 \%+4.0 \%)$. Dit is opmerklik dat die persentasie gemeentes waar een of minder psalms per Sondag gesing word, beduidend meer is as dié waar psalms twee of meer keer per Sondag gesing word.

Die grafiek toon dat die gebruiksfrekwensie van psalms uit die Liedboek (2001) laag is en dat psalmsang lae prioriteit in die liturgie van die erediens geniet.

\section{Die funksionaliteit van psalms}

Die funksionaliteit van psalms is geëvalueer deur drie fasette te ondersoek: die mate van aanwending, die gewildheid van psalms by gemeentelede, en die liturgiese aanwending daarvan. Deur vas te stel watter individuele psalms deur die gemeenteleiers aangewend is, kon spesifieke psalms sowel as die persentasie funksionele psalms bepaal word. 'n Verdere ondersoek het bepaal watter individuele psalms by gemeentelede gewild is, om te toets in watter mate gemeentes daarby aanklank vind. Hierdeur is spesifieke toeganklike psalms sowel as die persentasie psalms waarmee gemeentes hul kon vereenselwig, uitgewys. Liturgiese aanwending is as verdere ondersoekpunt aangewend om vas te stel in watter mate en in watter liturgiese elemente psalms gebruik word.

\section{Watter psalms word die meeste aangewend?}

Grafiek 2 toon watter psalms gemeenteleiers, soos leraars of musiekleiers, aanwend, en toon dus die funksionaliteit van spesifieke psalms sowel as die persentasie funksionaliteit van die psalmkorpus in sy geheel. Leraars kies gewoonlik liedere wat by die liturgie inskakel, terwyl musiekleiers dikwels liedere kies wat ter voorbereiding vir eredienste gesing word.

Volgens grafiek 2 is die algemene persentasie aanwending van psalms laag en word 'n geringe hoeveelheid psalms inderdaad gesing. Die volgende 14 psalms (georden vanaf hoogste tot laagste gebruiksfrekwensie) word deur meer as 30\% van die gemeentes gebruik:

- Psalm $100=84.0 \%$

- Psalm $146=76.6 \%$

- Psalm $33=73.3 \%$

- Psalm $23=66.6 \%$

- Psalm $84=64.0 \%$

- Psalm $48=58.0 \%$

- Psalm $130=56.0 \%$

- Psalm $42=50.6 \%$

- Psalm $116=49.3 \%$

- Psalm $111=46.0 \%$

- Psalm $18=44.6 \%$

- Psalm $66=37.3 \%$

- Psalm $118=32.0 \%$

- Psalm $8=30.0 \%$

Die data in grafiek 2 dui aan dat 89 uit die 150 (59.3\%) psalms deur sommige gemeentes gebruik word; dat 61 (40.6\%) psalms nie deur enige gemeentes gebruik word nie; dat 136 psalms $(90.7 \%)$ deur minder as 30\% gemeentes gebruik word, en dat $14(9.3 \%)$ psalms by meer as 30\% van die gemeentes gebruik word. Dit is ook kommerwekkend dat van die 60 nuwe psalmmelodieë in die Liedboek (2001), slegs drie (Ps 111/112, 29 en 5) noemenswaardig inslag kon vind en dat die vernuwings oënskynlik nie daarin kon slaag om meer entoesiasme vir die sing van psalms aan te wakker nie. 


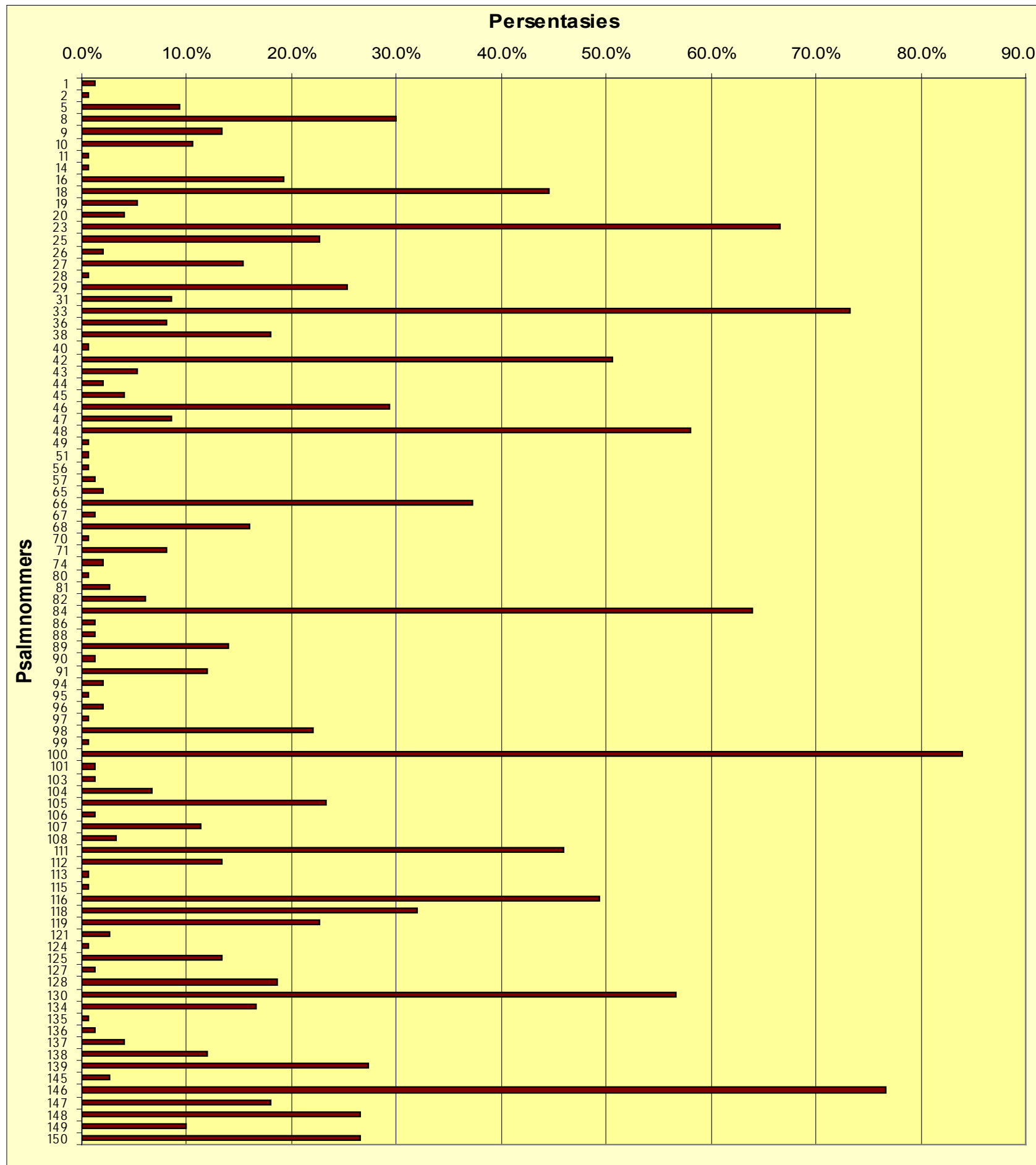

GRAFIEK 2

Psalms gebruik deur leraars en sangleiers

\section{Watter psalms is geliefd by gemeentelede?}

Nog 'n faktor wat die funksionaliteit van psalms kan beïnvloed, is die mate van gewildheid wat dit onder lidmate geniet. Gewilde psalms se woordinhoud en melodie vind gewoonlik inslag, omdat lidmate dit persoonlik of gesamentlik aan God kan rig. Hierdie vraag dien ook as kontrole vir die vorige vraag.

Volgens grafiek 3 is slegs tien (6.6\%) psalms by meer as $30 \%$ van gemeentes gewild. Hierdie tien psalms word hier in dalende volgorde van gewildheid gelys:

- Psalm $146=69.3 \%$

- Psalm $100=66.6 \%$
- $\quad$ Psalm $33=66.0 \%$

- Psalm $23=58.6 \%$

- Psalm $84=44.0 \%$

- Psalm $48=40.0 \%$

- Psalm $130=34.6 \%$

- Psalm $42=33.3 \%$

- Psalm $116=32.0 \%$

- Psalm $111=30.0 \%$

Die geheelbeeld van gewilde psalms is volgens grafiek 3 nie juis positief nie. Vier-en-sestig (42.7\%) psalms word wél by sommige gemeentes as gewild aangedui, maar dít moet in verhouding tot die klein aantal gemeentes waar dit gewild is, beskou word. Uit hierdie 64 psalms, is 43 by $10 \%$ en minder gemeentes gewild. 


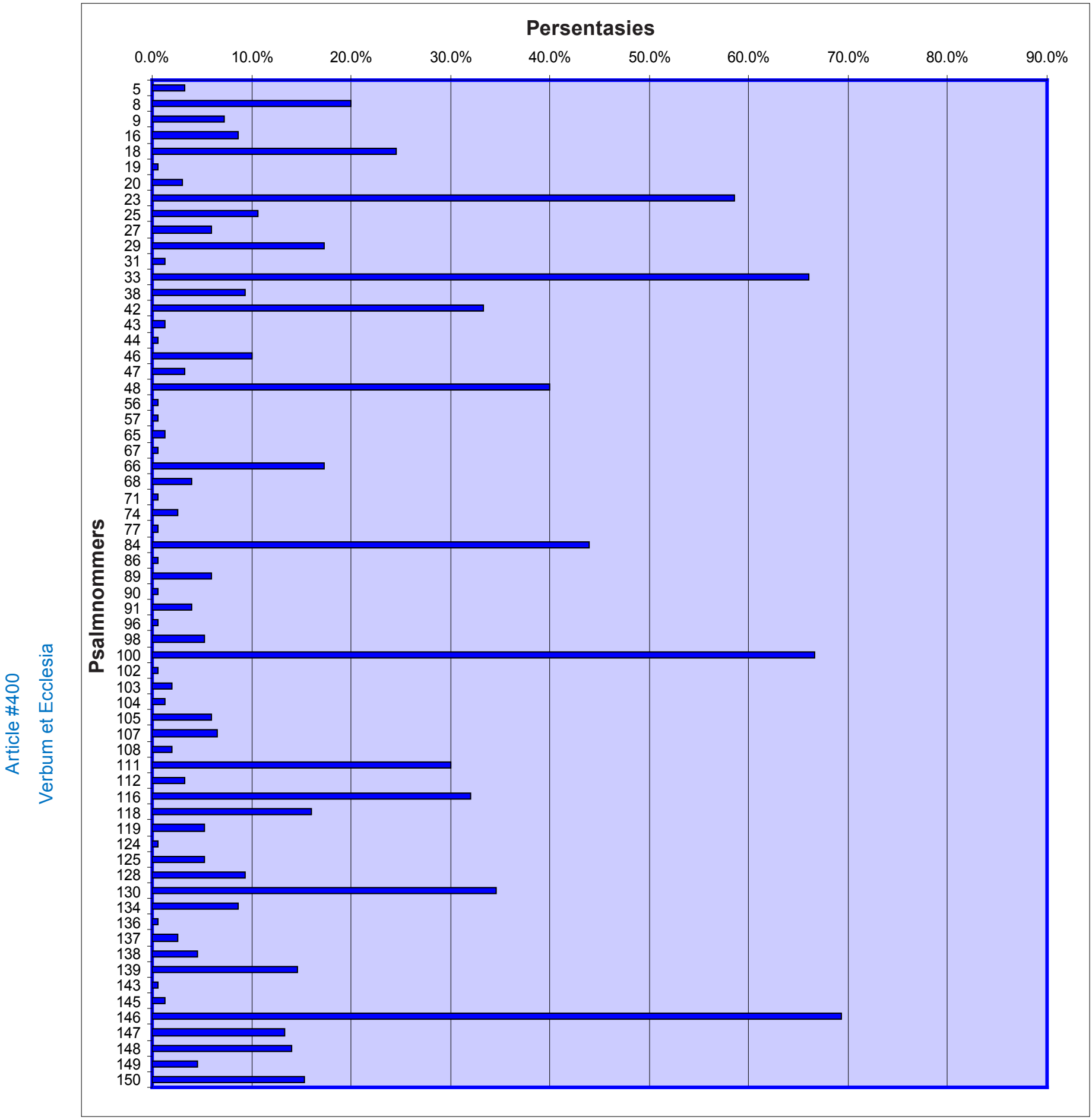

GRAFIEK 3

Psalms geliefd by lidmate

Saam met die 86 psalms wat op die grafiek uitgelaat is omdat dit by geen gemeente gewild is nie, kan die afleiding gemaak word dat altesaam $129(86+43)$ psalms $(86 \%)$ by $90 \%$ van die gemeentes ongewild is. Verder is 54 van hierdie 64 psalms by minder as $30 \%$ van die gemeentes gewild, wat tot die gevolgtrekking lei dat $140(86+54)$ psalms $(93 \%)$ by die meeste gemeentes minder gewild of geensins gewild is nie. Hieruit volg dat slegs tien $(6.7 \%)$ psalms by meer as $30 \%$ van die gemeentes gewild is.

Aangesien 'n gemeente slegs geliefde psalms met oorgawe sing, sal die data in grafiek 3 waarskynlik die mate van geesdrif weerspieël waarmee psalms gesing word. Die verskil van $16.6 \%$ tussen die aantal psalms wat in grafiek 2 en 3 gemeld word, hou waarskynlik verband met die verskil tussen die algemene siening van liturgiese leiers, en die behoeftes van gemeentelede. Grafiek 2 en 3 stem in 'n groot mate ooreen wat algemene profiel betref, behalwe dat die persentasie gewildheid ook gemiddeld $16.6 \%$ laer is as die aanwending van spesifieke psalms. Hieruit blyk dat daar 'n verband bestaan tussen die gebruiksfrekwensie en die geliefdheid van spesifieke psalms.

\section{In watter liturgiese elemente word psalms tydens} die erediens aangewend?

Liturgiese bruikbaarheid is waarskynlik die grootste bepaler van funksionaliteit by liturgiese musiek, en dra grootliks tot 


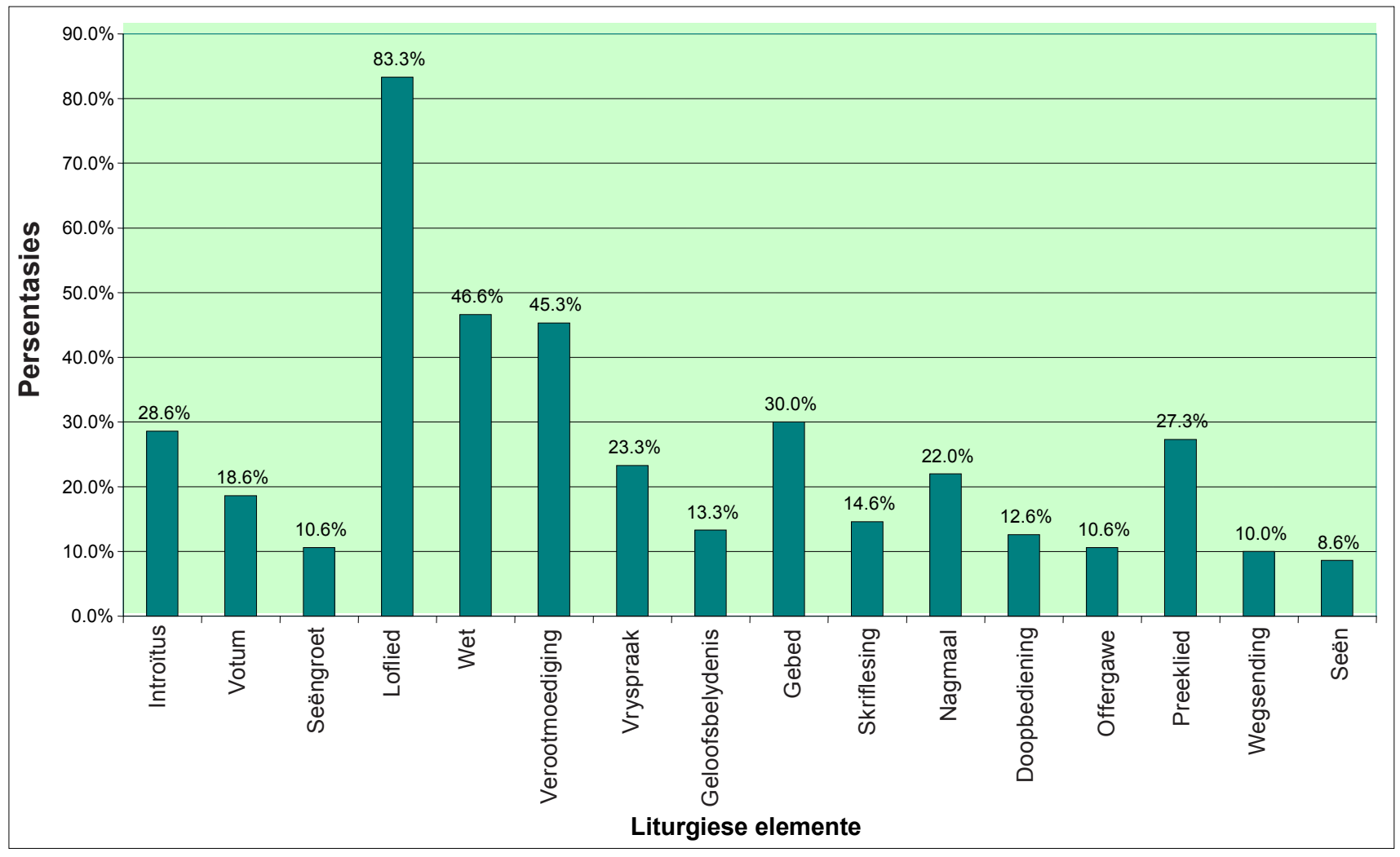

GRAFIEK 4

Liturgiese elemente waar psalmsang aangewend word

die gebruiksfrekwensie van psalms by. Grafiek 4 toon die resultate van ' $n$ ondersoek oor die aanwending van psalms in die verskillende liturgiese elemente.

Volgens grafiek 4 word psalms onderbenut in die meeste liturgiese elemente, met die opmerklike uitsondering van die hoë benutting $(83.3 \%)$ van psalms as lofliedere. Psalmgebruik in die voorhou van die wet en in verootmoediging is feitlik die helfte minder, op onderskeidelik $46.6 \%$ en $45.3 \%$. 'n Verdere daling tot $30 \%$, $28.6 \%$ en $27.3 \%$ word onderskeidelik by die gebed, introïtus en preeklied aangetoon. Psalms word by $23.3 \%$ van gemeentes in die vryspraak aangewend. Met die votum (18.6\%), Skriflesing (14.6\%) en geloofsbelydenis (13.3\%) daal psalmbenutting verder, terwyl psalms minimaal by die offergawe $(10.6 \%)$, uitsending $(10.0 \%)$ en seëngroet $(8.6 \%)$ gebruik word.

Volgens die grafiek word psalms by uitstek as lofliedere aangewend, terwyl daar ' $n$ algemene onderbenutting van psalms is in ander liturgiese handelinge in die erediens, soos die votum, Skriflesing, geloofsbelydenis en wegsending. Aangesien hierdie onderbenutting van psalms kommerwekkend is, is dit nodig om vas te stel watter faktore tot die situasie aanleiding gee.

\section{Praktiese faktore wat die liturgiese funksionaliteit van psalms beïnvloed}

Sekere praktiese faktore, soos die mate van gewildheid, die verstaanbaarheid of karakter van die psalmteks, die toeganklikheid of musiekstyl van die melodie, en die lengte en formaat van psalms, beïnvloed die funksionaliteit van psalms. Bewyse hiervan is in die objektiewe menings van gemeentes te vinde.

Redes vir die gewildheid of toeganklikheid van psalms Grafiek 5 bied ' $n$ uiteensetting van antwoorde oor moontlike redes vir die gewildheid van psalms. Respondente moes uit ses moontlike redes kies deur die toepaslike blokkie(s) op die vraelys te merk, of moes ' $n$ alternatiewe rede verstrek.

Volgens die data in grafiek 5 is bekendheid (64\%) by uitstek die oorwegende rede vir die gewildheid van sekere psalms. Mooi melodieë $(45.3 \%)$ dra meer as die woorde $(38.6 \%)$ tot psalms se gewildheid by. Die waardering vir treffende woorde $(38.6 \%)$, die sentimentele waarde (35.3\%) en die eenheid van woorde en musiek $(31.3 \%)$ van psalms lê op ongeveer dieselfde laer vlak van oorsaaklikheid. Sommige respondente het meer as een blokkie gemerk, terwyl slegs twee $(1.3 \%)$ respondente 'ander redes' gemerk het (dog sonder om verdere besonderhede te gee). Hierdie data stem ooreen met die gegewens in grafiek 2 en 3, waar bevind is dat die mees gebruikte en die gewildste psalms ook die bekendstes is.

Praktiese voorbeelde van gewilde psalms wat hierdie data bewys, is die liederwysies van Psalm 38 en 130, wat bekend en geliefd gebly het (kyk grafiek 3 ) ten spyte daarvan dat dit nooit in enige amptelike psalmbundel gepubliseer is nie; Psalm 18, waarvan die melodie deur die kerkvolk as 'mooi' ervaar word en gewild gebly het, hoewel dit vir 23 jaar nie in die psalmbundel geplaas is nie; Psalm 23 en 33, wat treffende woorde het en ook deur 'mooi' melodieë ondersteun word, en Psalm 146, wat sentimentele waarde het as liederwysie en geestelike volkslied, maar ook bekend is en treffende woorde het (kyk grafiek 2 en 3).

Hierdievoorbeelde toon dat, hoewel bekendheid hoog aangeslaan word, ' $n$ mooi melodie, die woordinhoud, sentimentele waarde, en die eenheid van teks en musiek tog 'n betekenisvolle bydrae tot die gewildheid en die funksionaliteit van psalms kan lewer. Psalms word op grond van die verskillende individuele faktore wat uitgewys is, maar ook weens die samehang van dié faktore, as geestesgoedere toegeëien.

\section{Evaluering van psalmtekste in die Liedboek (2001)}

Hierdie vraag moes bepaal in watter mate respondente die psalm-omdigtings in die Liedboek (2001) aanvaarbaar vind. Aangesien die aanvaarding van omdigtings en melodieë met 


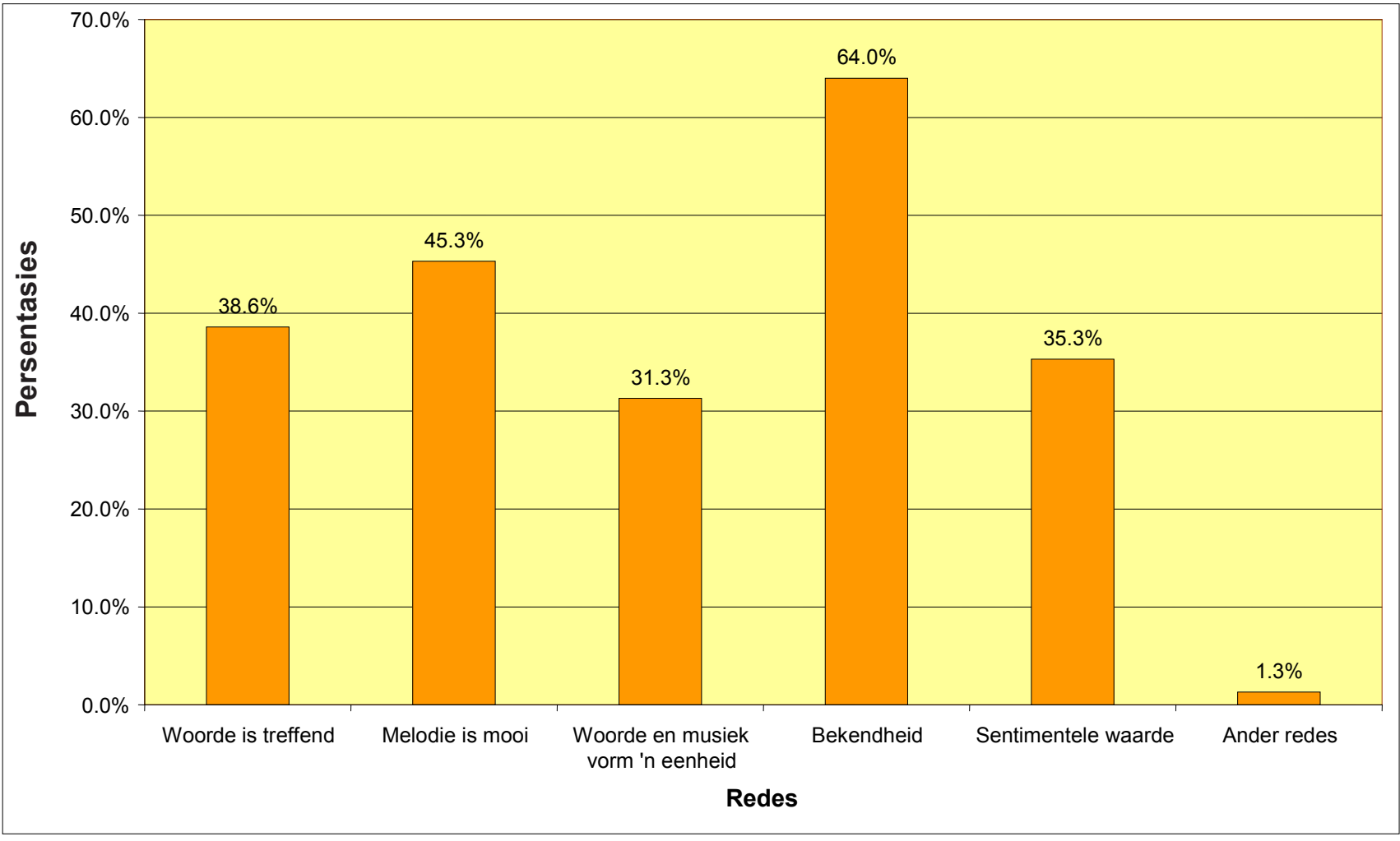

GRAFIEK 5

Redes waarom psalms gewild is

mekaar vergelyk word, word albei hierdie faktore in grafiek 6 aangedui. Redes vir spesifieke menings is aangevoer en word ook uiteengesit.

Volgens grafiek 6 word die psalmtekste in die Liedboek (2001) in die algemeen as ' $n$ verbetering op dié van die 1978-bundel beskou $(67.3 \%)$. Enkele respondente $(13.3 \%)$ meen dat sommige nuwe omdigtings ' $n$ verbetering is op die oues, terwyl $24.6 \%$ besware teen die nuwe psalmtekste het. Hierdie menings is hoofsaaklik gegrond op die mate waarin, en wyses waarop, die huidige omdigtings 'n verbetering op dié van die 1978-psalms toon.

Respondente het redes soos die volgende aangevoer waarom hulle die nuwe omdigtings verkies:

- 'Die omdigtings is in meer verstaanbare, eietydse, idiomatiese Afrikaans.'

- 'Dit is kreatief en goeie digkuns sodat ou waarhede nuut gesê word.'

- 'Die omdigtings is Skrifgetrou en teologies diepsinnig.'

- 'Gevoelens word betroubaar verwoord.'

- 'Omdigtings pas by die melodieë.'

(Respondente)

Die volgende kritiek is egter ook teen die nuwe omdigtings uitgespreek:

- 'Weerstand teen vernuwing', en gepaardgaande beswaar teen die verbreking van tradisie.

- 'Woordaksente klop soms nie melodies nie.'

- 'Die teks is minder poëties [as Totius se teks].'

- Dit is 'onpersoonlik' en 'te klinies'.

- 'Die teks is te teologies en onverstaanbaar.'

- 'Dit is te outyds.'

- 'Omdigtings [en strofes] is te lank.'

- 'Dit leer moeilik aan.'

- 'Dit bevat onaangename dinge waaroor mens nie wil sing nie', soos die wrede beskrywings wat in Psalm 79:2, 140:5, 141:6 en 44:3 voorkom.
- 'Die kulturele omstandighede van Bybelse psalms maak die teks vandag minder aanvaarbaar', soos dié wat in Psalm 45:6, 76:1-3, 108:4-7, 115:3-4 en 120:2-3 gebruik word.

(Respondente)

Hierdie vraag is besonder volledig beantwoord, en gemeentes het hul menings duidelik gemotiveer. Hieruit kan afgelei word hoe belangrik die omdigtings vir respondente is. Ten minste $67.3 \%$ van die gemeentes het nie die behoud van die Totiusberymings nodig geag nie. Hieruit kan afgelei word dat die Afrikaanse taalgebruik van hierdie berymings nie meer duidelik betekenis dra nie. Aangesien nuwe tekste betreklik maklik inslag gevind het, ten spyte daarvan dat die Totius-berymings 46 jaar lank gebruik is, kan afgelei word dat daar wél ' $n$ behoefte aan ' $n$ bygewerkte Afrikaanse omdigting bestaan het. Uit die kritiek wat gelewer is, blyk ook dat daar steeds ' $n$ behoefte aan psalmtekste bestaan wat van eenvoudiger en meer byderwetse Afrikaans gebruik maak en wat meer op eietydse behoeftes ingestel is. Veral die behoefte aan ' $n$ meer poëtiese of affektiewe benadering is geopper.

Hoewel die nuwe psalm-omdigtings grootliks geprys is weens die 'meer idiomatiese Afrikaans', het die funksionaliteit van psalms, volgens die resultate van die vraelys, nie daarby baat gevind nie. Sommige respondente het egter ook geldige kritiek gelewer. Kritiek teen die Cloete-omdigtings kom by uitstek van deskundige kerkmusici weens die metriese onversoenbaarheid daarvan met die Geneefse melodieë.

Ter samevatting kan die gevolgtrekking gemaak word dat, ten spyte van die kritiek wat teen die Cloete-omdigtings gelewer is, daar algemeen aanvaar is dat die Totius-berymings vervang moes word. Ook in gevalle waar die kritiek aandui dat die Totius-berymings meer 'poëties' is en meer emosie toon, was die kritiek nie teen die feit dat die psalms nuut omgedig is nie, maar wel teen sekere aspekte van die omdigtings.

Evaluering van psalmmelodieë in die Liedboek (2001)

Hierdie vraag het die aanvaarbaarheid van die nuwe psalmmelodieë getoets. Melodieë van Afrikaanse en ekumeniese 


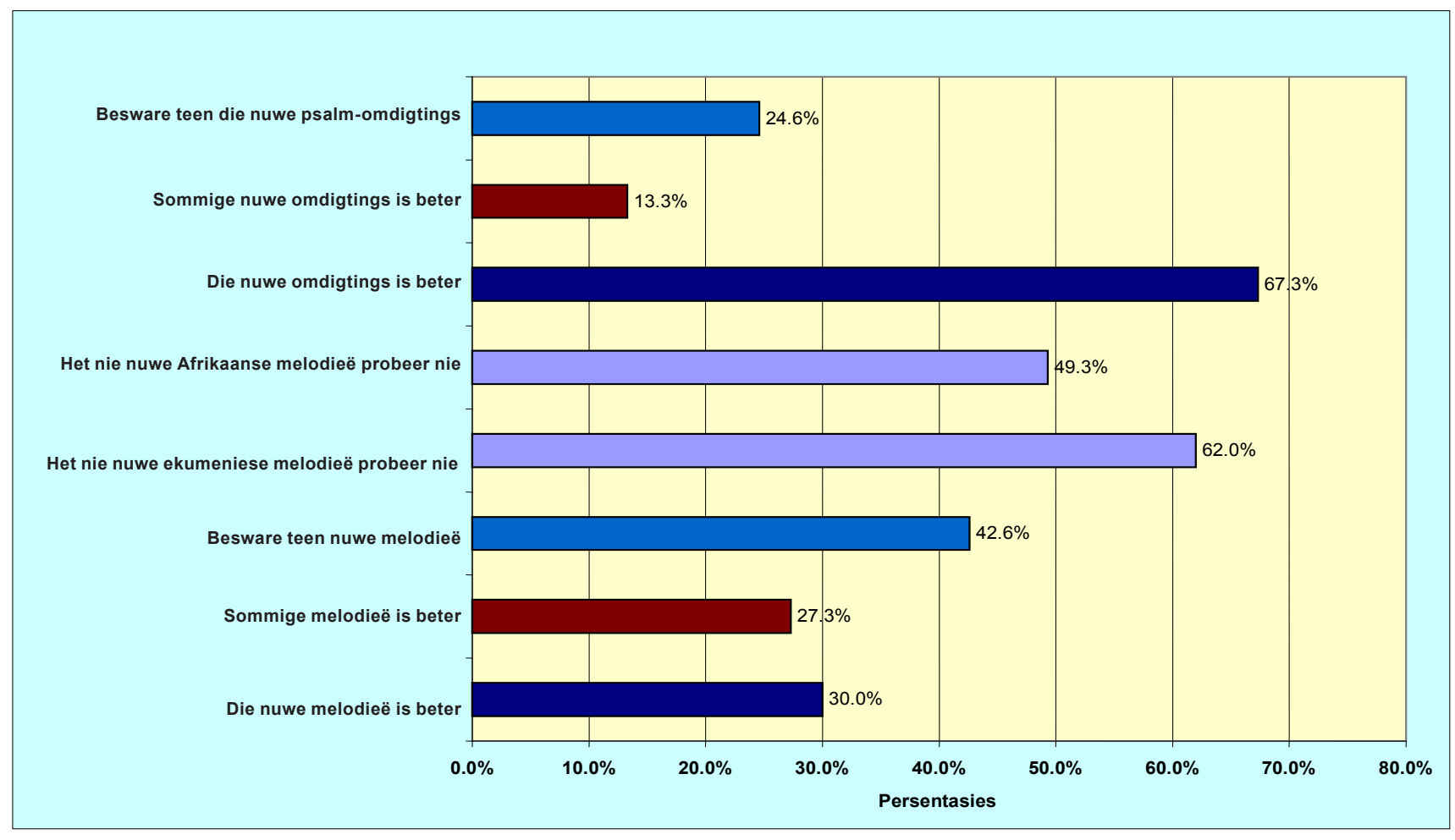

GRAFIEK 6

Menings oor nuwe omdigtings en medodieë

herkoms is afsonderlik getoets, en die response word op afsonderlike balke in grafiek 6 vertoon. Statistieke oor die aanvaarbaarheid van die nuwe omdigtings en die nuwe melodieë in die Liedboek (2001) word ook getoon.

Grafiek 6 toon dat $42.6 \%$ van die gemeentes die nuwe melodieë onaanvaarbaar vind, terwyl $27.3 \%$ sommige melodieë beter vind. Van al die gemeentes, vind $30.0 \%$ die nuwe melodieë meer aanvaarbaar. Dit is egter teleurstellend dat $49.3 \%$ van die gemeentes nie probeer het om die melodieë van Suid-Afrikaanse oorsprong aan te leer nie, en $62.0 \%$ van die gemeentes nie die ekumeniese melodieë probeer sing het nie.

Redes soos die volgende dui aan waarom psalmmelodieë, en daarom ook die psalms, moeilik inslag gevind het:

- 'Die Geneefse psalmmelodieë is onsingbaar'; 'die meeste psalmwysies val op die oor as onsingbaar'.

- 'Die Geneefse styl is volksvreemd'; 'dit spreek nie die gemiddelde Suid-Afrikaanse kerkganger aan nie'.

- 'Die nuwe psalmmelodieë word moeilik aangeleer.'

- 'Sommige nuwe melodieë klink soos die Geneefses.'

- 'Die psalms bied nie 'n aangename sangervaring nie'; 'dit sing nie lekker nie ...'; 'dit is nie gebruikersvriendelik nie', 'nie bruikbaar nie' en 'dit werk nie'.

- 'Mense vind nie aanklank by die woorde of die melodieë nie.'

- 'Ons gemeente is $60 \%$ bo 60 jaar, en selfs hulle verkies nie meer die psalms nie!'

- 'Daar bestaan 'n sielkundige weerstand teen psalmsang.'

- 'Die psalms is ongewild omdat dit onbekend is.'

(Respondente)

Uit voormelde menings kan afgelei word dat daar tans ' $n$ weerstand teen, of onsekerheid oor, die aanleer van psalmmelodieë bestaan: Meer respondente vind die nuwe melodieë onaanvaarbaar $(42.6 \%)$ as dié wat dit aanvaarbaar vind $(30.0 \%)$. Gemeentes wat die nuwe melodieë aanvaarbaar vind, is die helfte minder as dié wat die omdigtings (67.3\%) aanvaarbaar vind (vergelyk die twee donkerblou balke). Meer as die helfte van die gemeentes het nie probeer om die nuwe psalmmelodieë aan te leer nie - die twee ligpers balke wat hierdie data toon (onderskeidelik $49.3 \%$ en $62.0 \%$ ), verteenwoordig die hoogste persentasies ten opsigte van melodiese data. Die besware teen die melodieë $(42.6 \%)$ is ook heelwat meer as die besware teen die omdigtings ( $24.6 \%$ ) (vergelyk die twee blou balke). Spontane kritiek wat saam met die vraelys gelewer is, het bevestig dat nuwe psalmmelodieë moeilik aangeleer word.

Onsekerheid ten opsigte van die evaluering van melodieë blyk uit die opvallende verskil van 14 persentasiepunte tussen die gemeentes wat sommige nuwe omdigtings beter vind $(13.3 \%)$ en dié wat sommige nuwe melodieë beter vind (27.3\%); laasgenoemde is meer as dubbeld soveel as eersgenoemde (vergelyk die twee rooibruin balke). Daar is meer weerstand teen melodieë uit ekumeniese bronne $(62 \%)$ as teen dié van SuidAfrikaanse oorsprong (49.3\%) (vergelyk die twee ligpers balke).

Die volgende waarnemings, saam met die resultate in grafiek 5 , lei tot die gevolgtrekking dat bekende melodieë ' $n$ bepalende faktor in die geliefdheid van psalms is. Volgens grafiek 6 is die verandering in teks makliker aanvaar as die verandering in melodie. Dít staan in korrelasie met grafiek 3, wat toon dat bekende psalms gewild gebly het ten spyte van die verandering in teks. ' $n$ Groot hoeveelheid gemeentes (42.0\%) het aangedui dat die nuwe melodieë meer aanvaarbaar is, maar volgens grafiek 2 het hulle nogtans feitlik geen van hierdie melodieë aangeleer nie. Hierdie antwoorde moes aangepas word, en is dan op grafiek 6 by 'sommige' ingedeel, sodat die persentasie na $30.0 \%$ verander het.

Dit blyk dat nuwe psalmmelodieë in die Liedboek (2001) in die algemeen nie aanvaar is nie, en dat gemeentes traag is om psalmmelodieë aan te leer.

\section{Die behoefte aan volledige psalms}

In die vraelys is die behoefte aan die sing van volledige psalms getoets, omdat die vermoede bestaan dat die lengte van volledig omgedigte psalms en die inhoud van sommige strofes die rede is waarom volledige psalms nie in die erediens gesing word nie. 


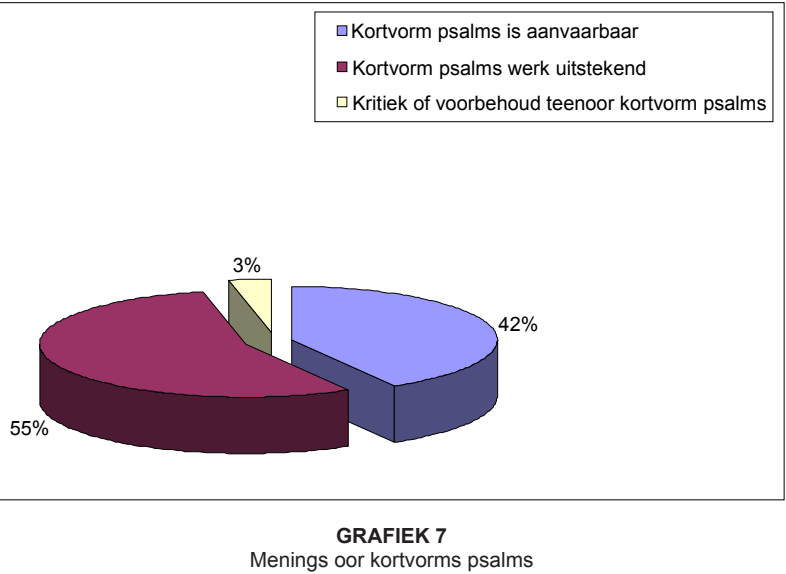

Die ingesamelde data het getoon dat $24.8 \%$ van die gemeentes waar moontlik volledige psalms gebruik, en dat $75.2 \%$ van die gemeentes slegs van bepaalde strofes gebruik maak. Hierdie data het voormelde vermoede bevestig. Die reaksie op hierdie vraag het voorts duidelik getoon dat leraars enersyds algemeen positief gesind is jeens die aanwending van volledige psalms, maar dat dit andersyds prakties onuitvoerbaar is.

Uit die data kan afgelei word dat die sing van volledige psalms nie prakties haalbaar is nie. Dit bevestig ook die kritiek wat by grafiek 6 bespreek is, naamlik dat die teksinhoud van sommige psalmstrofes veroorsaak dat gemeentes hulle moeilik daarmee vereenselwig.

\section{Die aanvaarbaarheid van kortvorm-psalms}

Die vraag oor die aanvaarbaarheid van kortvorm-psalms is bloot as ' $n$ bykomende vraag by die vraelys ingesluit, maar die verrassende reaksie daarop het die eietydse behoefte aan hierdie psalmformaat bevestig.

Volgens die data in grafiek 7 het $42 \%$ van die gemeentes aangedui dat hulle kortvorm-psalms positief ervaar. Die meeste gemeentes $(55 \%)$ het egter hul kommentaar verder gekwalifiseer deur hierdie psalmformaat as baie goed of uitstekend te beskryf Slegs $3 \%$ van die gemeentes het afwysend of krities gereageer.

Hoewel hierdie vraag bloot ' $n$ positiewe of negatiewe mening oor kortvorm-psalms vereis het, het respondente dit spontaan beskryf soos dit hierbo uiteengesit is. Gemeentes wat die psalmformaat goedkeur of uitstekend vind $(97 \%)$, is verreweg in die meerderheid. Hierdie data stem ooreen met dié in grafiek 3 , waar nuwe melodieë wat die beste inslag gevind het (Ps $111 / 112,29,5$ en 57) uit vier reëls per strofe bestaan, en grafiek 6 , waar beswaar aangeteken is teen lang melodieë omdat dit moeilik aanleer.

Volgens grafiek 7 blyk dat kort en kragtige psalms tans bruikbaar en gewild is. Uit die reaksie op hierdie vraag, saam met kritiek wat bykomend deur die vraelys ingewin is, kan afgelei word dat kort en gebruikersvriendelik vandag sinoniem is ten opsigte van die kerklied. Die oorweldigende reaksie ten gunste van die bruikbaarheid van kortvorm-psalms is ' $n$ aanduiding dat dit tans die mees funksionele psalmformaat is.

\section{BESPREKING}

\section{Die gebruiksfrekwensie van psalms}

Uit die resultate van die vrae wat die gebruiksfrekwensie van psalms uit die Liedboek (2001) getoets het, is dit duidelik dat psalmsang tans 'n lae prioriteit geniet. Dit blyk dat die aantal geleenthede en die aantal gemeentes waar psalms gesing word ontstellend laag is (kyk grafiek 1). Slegs 'n klein aantal psalms word gereeld gesing, terwyl die meeste psalms nié gesing word nie (kyk grafiek 2). Uit die grafieke is dit duidelik dat hoofsaaklik bekende psalms gesing word, ten koste van die uitbreiding van die psalmrepertorium. Ook die aantal gemeentes waar psalms voldoende gesing word, is laag.

Dit is duidelik dat gemeenteleiers die psalms waarskynlik nie doeltreffend aanwend nie; dat gemeentes in die algemeen nie die waarde van psalmsang besef nie; dat daar nie ' $n$ behoefte of begeerte bestaan om dit te sing nie, en dat slegs bekende psalms meestal gesing word sodat ' $n$ beperkte verskeidenheid psalms inderwaarheid aangewend word. Indien psalms selde en by min geleenthede gesing word, is daar min geleentheid om die bestaande psalmrepertorium in stand te hou of uit te brei. In hierdie omstandighede sal die gebruiksfrekwensie van psalms waarskynlik verder afneem.

\section{Die funksionaliteit van psalms}

Psalms is funksioneel indien die teks en melodie die psalminhoud doeltreffend oordra en dit gemeentes in so ' $n$ mate kan roer dat hulle dit as persoonlike of gesamentlik gesonge gebede aan God kan rig. Die teendeel gebeur egter wanneer tekste en melodieë nie voldoende by mekaar aansluit om hartgrondige liturgiese dialoog teweeg te bring nie, en psalmsang betekenislose lippetaal word of slegs deel van die erediensritueel uitmaak.

Hoewel die meeste respondente aangedui het dat hulle die nuwe omdigtings as ' $n$ verbetering beskou, is die volgende grondige besware tog teen die psalmtekste geopper: 'n gebrek aan emosie of uitdrukking, verouderde woordgebruik, gedwonge woordordes, verskuilde liturgiese of teologiese temas, kultuurvreemde simboliek, wreedhede, en breedsprakige psalmtekste met lang of baie strofes. Hieruit blyk dat, hoewel die taalgebruik as meer idiomatiese Afrikaans verwelkom is, die kerkvolk tog nog probleme ervaar om dit as natuurlike spreekbuis aan te wend.

Sterk kritiek is teen die Geneefse psalmmelodieë uitgespreek, omdat dit ' $n$ vreemde melodiese en ritmiese styl handhaaf en dít onnatuurlike woordklem tot gevolg het. Aangesien hierdie melodieë in die grootste persentasie psalms aangewend word, word die psalms in die algemeen beskryf as 'volksvreemd', 'dit spreek nie aan nie', 'dit werk nie', en 'mense vind nie aanklank by die woorde of die melodieë nie'. Een kritikus het die algemene gesindheid van die kerkvolk opgesom as ' $n$ 'sielkundige weerstand teen psalmsang'.

Ondoeltreffende psalmsang lei onwillekeurig tot 'n lae gebruiksfrekwensie, en 'n lae persentasie gemeentes wat psalms voldoende aanwend (kyk grafiek 2). Verdere simptome van wanfunksionele psalms is die ongewildheid daarvan by die meeste gemeentes (grafiek 3). Dit lei tot ' $n$ beperkte verskeidenheid psalms, en ' $n$ gebrek aan inisiatief om psalms kreatief in die verskillende handelinge in die erediens aan te wend (grafiek 4).

Aangesien liturge of musiekleiers funksionele psalms vir gebruik in die eredienste kies, sal die lae gebruiksfrekwensie van individuele psalms, en die beperkte aantal en verskeidenheid psalms wat aangewend word, ook die wanfunksionaliteit daarvan weerspieël. Die samehang van voormelde faktore veroorsaak ' $n$ bose kringloop, wat slegs deur drastiese ingrype omgekeer kan word.

\section{Die liturgiese bruikbaarheid van psalms}

Die psalms is onder meer die betroubaarste liturgiese bron wat ons in die Bybelse tradisie ontvang het (Brueggemann 1984:15) en bevat inhoudelik alle elemente van die eietydse erediens. Nogtans is daar tans faktore wat die funksionele benutting van psalms as integrale deel van die erediensdialoog belemmer, soos reeds hierbo verduidelik is. Die laaste vraag op die vraelys het respondente die opsie gelaat om 'enige bykomende kommentaar oor die psalmbundel of oor gemeentelike psalmsang' te lewer. Menings wat hierdeur ingewin is, saam met die kritiek wat by grafiek 6 gelewer is, het waardevolle inligting verskaf wat aangewend kan word om in behoeftes op grondvlak te voorsien. Onder andere het verskillende redes vir die onderbenutting van psalms hieruit na vore gekom. 


\section{Redes vir die onderbenutting van psalms}

Die uitwys van psalms vir liturgiese gebruik blyk 'n probleem te wees. Volgens respondente vind leraars dit om die volgende redes moeilik om psalms te kies wat tydens die erediens vir gemeentelike liturgiese deelname aangewend kan word:

- Weens die afwesigheid van doelmatige registers waarin temas en liturgiese elemente uiteengesit word, is dit moeilik om in erediensbeplanning geskikte psalms as deel van die liturgiese dialoog uit te wys.

- Liturgiese elemente of temas is selde as bruikbare eenhede per strofe omgedig; lang strofes veroorsaak dikwels dat verskillende temas in een strofe saamgegroepeer word (kyk Ps 82, 138 en 147).

- Die styl van psalmtekste verskil te veel van die omgangstaal, byvoorbeeld 'Moet nie u oor van my af keer', Ps 28:1), en dit toon te min emosie of is nie uitdrukkingsvol genoeg nie, byvoorbeeld 'Die Here sien hom in sy goedheid aan' (Ps 1:1).

- Daar is beswaar gemaak teen 'hoë' teologiese terme, soos 'toorn', 'mededoë' en 'lydsaam'; verouderde uitdrukkings, soos 'gramskap', 'swygsaam' en 'kasty'; onnatuurlike woordorde, byvoorbeeld 'Mag hul u liefde toegewy wees ...' (Ps 5:5), of onverstaanbaarheid van die taal, soos in 'Deur my gloei die koors van vure' (Ps 38).

- Woordaksente val dikwels nie saam met die musikale aksente nie en het ' $n$ moeilike eenwording van teks en melodie tot gevolg, soos in Psalm 36, 54 en 79.

- Lang en moeilike melodieë veroorsaak dat psalms onbekend is en daarom die liturgie moeilik laat vloei, soos Psalm 7, 32 en 73 . Wanneer leraars ' $n$ geskikte psalmteks vind, is die melodie dikwels nie bekend genoeg om te gebruik nie.

- Die onsingbaarheid van die Geneefse psalmmelodieë, en enige melodiese of ritmiese tendense wat daaraan herinner, byvoorbeeld Psalm 15, 22 en 49, het die sterkste kritiek ontlok.

- Kulturele verskille pla ook, byvoorbeeld waar onbekende lewensomstandighede beskryf word, soos ' Hul sal in skerwe voor jou septer lế' (Ps 2:4); waar vreemde geografiese name gemeld word, byvoorbeeld 'Sigem', 'Gilead' en 'Filistea' (Ps 108), of onaangename dinge, soos wreedhede, beskryf word, byvoorbeeld ' $\mathrm{Hul}$ is gemaal en uitgestrooi ... vertrap tot modder in die straat' (Ps 18:10)

Omdat liturge verkies om liedere te gebruik wat doeltreffend in die liturgie funksioneer, word psalms vermy. Voormelde faktore het daartoe aanleiding gegee dat psalms steeds minder bekend en geliefd geword het; dat ' $n$ negatiewe gevoel teenoor psalms in die algemeen opgebou het, en dat ' $n$ moedeloosheid vir die sing en aanleer daarvan posgevat het.

\section{Verbetering van psalmbenutting}

Om die benutting van psalms in die huidige opset te verbeter, sal dit nodig wees om die psalms wat wél bruikbaar is uit te wys; dit doelmatig aan te wend, en doelbewus te propageer. Psalms wat hiervoor in aanmerking behoort te kom, is onder meer die tien psalms wat in grafiek 3 as die mees geliefde psalms uitgewys is.

Psalms wat in 'n gemeente-opset lewenskragtig behoort te wees (volgens grafiek 5), is bekende psalms wat gereeld gebruik word, met 'mooi melodieë' wat moontlik van volksidiomatiese bronne of herkenbare melodiese eienskappe gebruik maak; wat treffende en verstaanbare tekste het en spirituele begrippe poëties verklank; wat die geestelike sentiment van 'n samelewing weergee, en waaraan die samevloeiing van teks en melodie oortuigingskrag verleen.

Die Liedboek (2001) bevat wél bruikbare nuwe psalms, met toeganklike teks en melodieë, wat nog nie algemeen bekend is nie en wél ontgin kan word, soos Psalm 14, 15, 37/40/70, 41, 92, 126, 127 en 139 (die eerste melodie).

Die gewildheid van kortvorm-psalms (grafiek 7) toon egter dat daar tans ' $n$ dringende behoefte aan ' $n$ vernuwende benadering tot psalmsang bestaan wat aandag behoort te geniet. Nuwe psalms wat hierdie formaat saam met eenvoudige dog treffende woorde en ' $n$ toeganklike melodiestyl gebruik, is in aanvraag. $\mathrm{Om}$ in die behoefte aan vernuwing in die NG Kerk te voorsien, is die VONKK- (Voortgesette Ontwikkeling van Nuwe Klassieke Kerkmusiek-) taakgroep in die lewe geroep, wat tans onder meer aan vernuwende psalms werk. Sedert 2009 word nuwe psalms gereeld op die VONKK-webwerf geplaas.

\section{Die voortbestaan van psalms in die Liedboek (2001)}

Vir die voortbestaan van die psalms in die Liedboek, behoort die bekende psalmrepertorium gereeld gesing en nuwe psalms proaktief aangeleer te word. Hierdie twee moontlikhede kan ondersoek word deur die ingesamelde data saam met praktykgebaseerde kennis aan te wend.

\section{Die moontlikheid dat bestaande psalms in stand gehou kan word}

Vir die instandhouding van die bestaande psalmkorpus, behoort dit gereeld by genoeg gemeentes gesing te word. ' $n$ Voldoende aantal psalms om die bestaande psalmsangtradisie te onderhou, behoort ook aangewend te word.

Volgens die resultate in grafiek 1 sing $36 \%$ van die gemeentes een psalm per Sondag, en sing $45 \%$ van die gemeentes minder as een psalm per Sondag. Daar kan dus aanvaar word dat ' $\mathrm{n}$ psalmbundel met 150 psalms nie by hierdie $(45 \%+36 \%=81 \%)$ gemeentes sal kan voortbestaan nie. Die moontlikheid bestaan dat dit by die oorblywende $(100 \%-81 \%=19 \%)$ gemeentes kan oorleef. By $15 \%$ van hierdie gemeentes word psalms twee keer per Sondag gesing: Hiér kan dit moontlik in stand gehou word. By $4 \%$ van die gemeentes word psalms meer as twee keer per Sondag gesing: By dié gemeentes behoort dit goed te kan oorleef. Die gemiddelde van die totaal van hierdie persentasies skets die volgende prentjie van die oorlewingsmoontlikheid van psalmsang in die gemeentes van die NG Kerk:

$$
(4 \%+15 \%) \div 2=9.5 \%
$$

Psalmsang kan dus in ' $n$ geraamde $9.5 \%$ gemeentes oorleef.

Slegs 14 psalms $(9.3 \%)$ word tans in meer as 30\% van gemeentes gesing, en tien psalms $(6.7 \%)$ is by meer as $30 \%$ van gemeentes geliefd. Die gemiddelde van hierdie twee persentasies dui by benadering die persentasie psalms aan wat kan oorleef:

$$
(9.3 \%+6.7 \%) \div 2=8 \%
$$

Uit die bestaande psalms, kan daarom ' $n$ geraamde $8 \%$ oorleef.

Uit bostaande kan afgelei word dat die bestaande psalmtradisie tans ' $n$ uiters skrale oorlewingsmoontlikheid het. Tog is daar ' $n$ geraamde $8 \%$ individuele psalms wat in so 'n mate inslag gevind het dat dit altyd deel van die NG Kerk se liedereskat sal uitmaak. Die moontlikheid om nuwe psalms uit die Liedboek (2001) in die huidige klimaat aan te leer, kan ook verdere lig werp op die situasie werp.

\section{Die moontlikheid dat nuwe psalms uit die Liedboek aangeleer kan word}

In die praktyk is dit feitlik onmoontlik om nuwe psalms tydens die erediens aan te leer. Die enigste geskikte geleentheid vir die aanleer van nuwe psalms is tydens die inleidende sang voor eredienste. Daarom sal die gemeentes wat voor die erediens psalms sing, meer psalms kan aanleer.

Hoogstens een lied kan gewoonlik voor ' $\mathrm{n}$ erediens aangeleer word. Die 150 psalms maak 'n kwart van die 602 liedere in die Liedboek (2001) uit. Die moontlikheid dat ' $n$ psalm vir die voorsang gekies sal word, is dus 1 uit 4 (dit wil sê $25 \%$ ). Die mate van entoesiasme vir psalms, en vir die aanleer van nuwe psalms, sal ook die keuse beïnvloed, want slegs indien sistematiese beplanning gedoen word, sal psalms by die aanleer van nuwe liedere ingesluit word. 
Die persentasie gemeentes waar psalms voldoende gesing word sodat psalms aangeleer kan word, kan by benadering bereken word.

Die data in grafiek 1 het aangedui dat $81.3 \%$ van gemeentes een maal per Sondag of minder gereeld psalms sing. Om nuwe psalms aan te leer, moet psalms normaalweg meer as een maal per Sondag gesing word. Dít is die geval by slegs $(100 \%-81.3 \%)$ gemeentes, dus:

$100 \%-81.3 \%=18.7 \%$

Verder kan die gemeentes waar psalms voor die erediens gesing word, in berekening gebring word.

Omdat dit feitlik onmoontlik is om psalms gedurende die erediens aan te leer, moet die hoeveelheid gemeentes wat psalms voor, en dié wat psalms tydens die erediens sing (onderskeidelik $62 \%$ en $84 \%$ ) met mekaar in verband gebring word. Die persentasies $62 \%$ en $84 \%$ staan in die benaderde verhouding 3 tot 4 ; dus 'n driekwart van $18.7 \%$ :

$$
3 / 4 \times 18.7 \%=14.025 \% \text {, afgerond tot } 14.03 \%
$$

Die moontlikheid dat ' $n$ psalm vir die voorsang gekies kan word, is egter nie 'n gegewe nie.

Vier tot vyf liedere word gewoonlik by die inleidende sang gesing, en hoogstens een lied kan normaalweg per geleentheid aangeleer word. Daar is reeds verduidelik dat die 150 psalms ongeveer ' $n$ kwart van die 602 liedere in die Liedboek (2001) uitmaak. Die moontlikheid dat 'n psalm aangeleer sal word, is daarom 150 uit 602, uitgedruk as 'n deel van die $14.03 \%$ van gemeentes waar psalms voor die erediens gesing word, dus:

$150 / 602 \times 14.03 \%=24.9 \%$ van $14.03 \%$

$=(150 \div 602) \%$ van $14.03 \%$

$=24.9 \%$ van $14.03 \%$

$=((24.9 \times 14.03 \%) \div 100) \%$

$=(24.9 \times 14.03) \%$

$=3.49 \%$

Die motivering om psalmsang te bevorder is die laaste faktor in die benaderde berekening van die moontlikheid dat nuwe psalms aangeleer kan word.

Respondente se kommentaar het $11.1 \%$ positiewe en $88.9 \%$ negatiewe opmerkings ten opsigte van psalms in die Liedboek (2001) ingesluit. Omdat die gesindheid jeens psalms ' $n$ invloed sal hê op die gewilligheid om nuwe psalms aan te leer, word dit in berekening gebring. Dít beteken dat daar ' $n$ 11\% moontlikheid uit $3.49 \%$ bestaan dat ' $n$ psalm aangeleer kan word, dus:

$$
\begin{aligned}
& 11 \% \text { van } 3.49 \%=11 \% \times(3.49 \%) \\
& =((11 \times 3.49) \div 100) \% \\
& =0.38 \%
\end{aligned}
$$

Die benaderde persentasie moontlikheid dat nuwe psalms in die huidige opset in die NG Kerk aangeleer kan word, is dus minder as nul. Slegs by gemeentes waar werklik moeite gedoen word, sal nuwe psalms aangeleer kan word.

\section{GEVOLGTREKKING}

Die empiriese studie het getoon dat die meeste psalms in die Liedboek (2001) nié in die kerksangrepertorium van die NG Kerk opgeneem is nie. Grafiese gegewens oor gebruiksfrekwensie en funksionaliteit sowel as respondente se menings het beklemtoon dat hoofsaaklik bekende psalms herhaaldelik gesing word.

Hoewel daar ' $\mathrm{n}$ groot behoefte aan meer byderwetse psalmomdigtings bestaan het, en die huidige psalms oorwegend as ' $n$ groot verbetering beskou word, kon dit tog nie oortuigend inslag vind om die aanwending van psalms voldoende te stimuleer nie. Volgens die kritiek wat gelewer is, blyk dat die taalgebruik, en veral die melodieë, steeds uit pas is met die behoeftes van gemeentes in die eietydse, Afrikaanse kultuur, en dat die geesdrif vir die sing en aanleer van psalms as gevolg daarvan gedemp is.
Uit al die fasette van die probleemsituasie wat geskets is, plus die kritiek wat deur respondente gelewer is, kan een kernprobleem egter uitgewys word: die wanfunksionaliteit van die psalms. $\mathrm{Na}$ aanleiding van die evaluering van psalmtekste en melodieë, sowel as die bespreking van die funksionaliteit van psalms, dui die respondente se kommentaar daarop dat gemeentes dit moeilik vind om hulle voldoende met die tekste en melodieë van psalms te vereenselwig, en om psalms dus as persoonlike of gesamentlike gebede aan God te rig. Gevolglik het psalmsang in die meeste gemeentes weggekwyn tot ' $n$ kragtelose liturgiese handeling; dit het bloot as ' $\mathrm{n}$ tradisie bly voortbestaan. Wanneer psalms nie tot die verheerliking van God aangewend word nie, mis dit die oorspronklike doel, en het dit die fundamentele oortuigingskrag daarvan verloor.

Die studie het ernstige tekortkomings en struikelblokke aan die lig gebring. Voortgaande navorsingsdoelwitte om psalmsang te laat herleef, kan soos volg benader word: Watter taalinkleding kan die Bybelse psalminhoud in eietydse konteks in die lewe roep? Watter eenvoudige psalmpoësie kan aan die hartstaal van die kerkvolk uitdrukking gee? Kan die basiese psalminhoud nuut belig word deur dit aan die hand van aktuele, eietydse probleme en behoeftes te benader? ' $n$ Verdere studie sou ' $n$ soektog van stapel kon stuur na geskikte melodieë, om eklekties uit verskillende klassieke en kontemporêre style en liedere te kies wat wél waardige draers van psalmtekste kan wees. Hierdie style en voorbeelde behoort onder meer aan eietydse aanbidding te kan uitdrukking gee.

Die empiriese studie het die lae gebruiksfrekwensie, wanfunksionaliteit, ongewildheid en beperkte liturgiese aanwending van psalms bevestig. Psalms se lae gebruiksfrekwensie lei tot onbekendheid en ongewildheid, wat weer tot gebrekkige liturgiese aanwending lei. Die studie het getoon dat die psalms slegs in die ongeveer 9.5\% gemeentes kan oorleef waar die waarde van psalmsang beklemtoon word, bestaande psalms gereeld gesing word, en nuwe psalms aangeleer word, en dat ' $n$ benaderde $8 \%$ van die bestaande psalmkorpus kan oorleef. Daarom kan die gevolgtrekking gemaak word dat psalmsang in die NG Kerk in die huidige formaat besig is om in onbruik te verval.

\section{LITERATUURVERWYSINGS}

Barnard, A.C., 2001, 'Voorwoord by die Psalms', in Liedboek van die Kerk, pp. 11-17, NG Kerk-uitgewers, Wellington.

Brueggemann, W., 1984, The Message of the Psalms. A Theological Commentary [Die boodskap van die Psalms. Teologiese kommentaar], Augsburg Publishing House, Minneapolis.

Fourie, F.P., 2000, "n Geskiedenis van die kerklied in die Nederduitse Gereformeerde Kerk', DTh-proefskrif, Departement Musiek, Universiteit van Suid-Afrika.

Jankowitz, H.J., 2009, 'Die praktyk van liturgiese psalmsang in die NG Kerk in Suid-Afrika en Namibië', PhD (Musiek)proefskrif, Departement Musiek, Noordwes-Universiteit.

NG Kerk, 2001, Liedboek van die Kerk vir gebruik by die erediens en ander byeenkomste, 2001, NG Kerk-Uitgewers, Kaapstad.

Roux, E., 1985, 'Grondbeginsels van die Gereformeerde Kerklied met verwysing na die 1978-Psalm en Gesangboek', DPhil-proefskrif, Departement Musiek, Universiteit van Pretoria.

Strauss, M., 2005, 'My allerbeste vir die Allerhoogste. Kan/wil ek liturgies 'n verskil maak in 'n post-Christelike tyd?', Vir die Musiekleier 32, 7-16.

Viljoen, M., 1997, 'Sentiment en die lied van die Nederduitse Gereformeerde Kerk: 'n Inhoudsanalitiese perspektief', ongepubliseerde MMus-verhandeling, Departement Musiek, Universiteit van die Oranje Vrystaat.

Vos, C.J.A., 2005, Theopoetry of the Psalms [Teo-poësie van die Psalms], Protea Book House, Pretoria. 